\title{
miR-7b Promoter Contains Negative Gene Elements
}

\author{
Ji-Woong Choi ${ }^{1}$ and Heon-Jin Lee ${ }^{1,2} \star$ \\ ${ }^{1}$ Department of Oral Microbiology, School of Dentistry, ${ }^{2}$ Brain Science and Engineering Institute, Kyungpook National University, Daegu \\ 700-412, Korea
}

Received August 10, 2011 /Revised December 5, 2011 /Accepted December 6, 2011

\begin{abstract}
The typical miRNA and its nearby host gene are co-expressed by sharing the same promoter. We assumed that miR-7b and its host gene FICT might use an identical promoter for their brain specific gene expression. Sequence comparison of the genomic DNA of mouse miR-7b, human miR-7-3 and their host genes by using the bioinformatic tools revealed high sequence homology and several putative transcription factor-binding sites on the promoter region. In order to probe the hypothesis we used a luciferase vector system into which we cloned the $5^{\prime}$ upstream conserved region of miR-7b and FICT. The putative promoter region showed decreased luciferase activity, suggesting that the $5^{\prime}$ upstream of miR-7b and FICT contain a negative regulator for gene expression.
\end{abstract}

Key words : miRNA, promoter, gene regulation, DNA element, cis element

\section{Introduction}

MicroRNAs (miRNAs) are non-coding 21-23 nt (nucleotide) RNA molecules that regulate the expression of other genes by inhibiting translation of target mRNAs in animals and plants [1]. Unlike other small RNAs, miRNAs are processed from larger precursors (pri-miRNA) that are transcribed from non-protein-coding genes by RNA polymerase II and then processed into precursors of miRNAs (pre-miRNA) [8]. The pre-miRNAs form self-complementary hairpin structures that are processed by a type III ribonuclease, Dicer, in animals [10].

Usually, intronic miRNAs are co-expressed with their host gene by sharing the same promoter [2]. MiRNA miR-7b and its host gene (FICT) are prominently expressed in the hypothalamus and other brain areas [6]. Indeed, distribution of both miR-7b and FICT suggest they share regulatory elements within the promoter region [6]. In addition, the human homologue of miR-7b (miR-7-3) and its host gene PGSF1 also reveal brain-specific (including hypothalamus and pituitary) gene expression patterns $[2,4,6,12]$.

Although identification of the DNA elements and transcription factors responsible for tissue- and cell-specific gene expression in the nervous system are less clarified, an increasing number of transcription factors and DNA elements involved in neuron-specific gene regulation have been char-

*Corresponding author

Tel : +82-53-660-6832, Fax : +82-53-425-6025

E-mail : heonlee@knu.ac.kr acterized [7,11]. Interestingly, many neural-specific genes use negative regulatory mechanisms to drive their specific expression in neural cells [9].

In this study, we investigated the promoter region of miR-7b to elucidate brain tissue specific DNA elements. We used luciferase reporter constructs containing regions of the miR-7b $5^{\prime}$ upstream region to test the promoter activity by transient transfection into various cell lines. Here, we report that the miR-7b promoter region that is homologous to human miR-7-3 contains negative regulatory sequences for gene expression.

\section{Materials and Methods}

\section{RNA isolation and $\mathrm{qRT}-\mathrm{PCR}$}

Total RNA was isolated by mechanical disruption of indicated tissues with QIAZOL reagent (Qiazen, Valencia, CA, USA) following the manufacturer's protocol. For FICT qRT-PCR, cDNA was synthesized from an equivalent amount of total RNA from each sample using Superscript first strand synthesis system (Invitrogen, Carlsbad, CA, USA). The following forward and reverse primers were used FICT forward 5'-ACGAAGAGACTAGGCTTCAGCA-3 and FICT reverse $5^{\prime}$-CCTGTACTCTGTGAGTTTGAAG-3; $\beta$ -actin forward $5^{\prime}$-TTGCTGACAGGATGCAGAAG-3 ${ }^{\prime}$ and reverse 5'-CAGTCCGCCTAGAAGCATTT-3'.

Real-time reactions were carried out using SYBR Green PCR master mix (Applied Biosystems, Foster City, CA, USA) using the ABI PRISM 7500 sequence detection system 
(Applied Biosystems, Foster City, CA, USA). The following conditions were used for q-PCR: $94^{\circ} \mathrm{C}$ for $30 \mathrm{~s}, 60^{\circ} \mathrm{C}$ for 30 $\mathrm{s}$, and $72^{\circ} \mathrm{C}$ for $30 \mathrm{~s}$ in 40 cycles. Relative expression levels of mRNA were normalized to $\beta$-actin and analyzed for statistical significance.

miR-7b expression patterns were evaluated using TaqMan MicroRNA Assays (Applied Biosystems, Foster City, CA, USA). The assay includes two steps: generation of cDNA by reverse transcription reaction and TaqMan real-time PCR assay. In brief, miRNAs in the samples were converted into cDNA using miR-7b specific stem-loop reverse transcription primers. After cDNA conversion, the quantity of mature miRNAs was evaluated using specific TaqMan real-time PCR primers and probes. Real-time PCR was done using GeneAmp Fast PCR Master Mix (Applied Biosystems, Foster City, CA, USA) and ABI 7500 real-time PCR machine. All reactions were done in duplicate. Transcription level of U6 was used as endogenous control for analysis.

\section{Bioinformatics}

PGSF1 (GeneBank accession no. AB058893.2) and FICT (GeneBank AK038632) mRNAs and their adjacent genomic DNA sequences were obtained from the NCBI database (http://www.ncbi.nlm.nih.gov). Homology sequences were compared using the web based software Multalin (http://multalin.toulouse.inra.fr/multalin/multalin.html) [3]. Transcription factor biding sites were analyzed using the web based software Consite (http://asp.ii.uib.no:8090/cgi-bin/CONSITE/consite/).

\section{Generation of DNA constructs}

The miR-7b and FICT $5^{\prime}$ upstream (451 bp) region that has homology with human counterpart PGSF1 was amplified by PCR using the primers 5 -GGTACCGAGCTCAAA AAGAAAACAAAAGCAGC-3' and 5'-AGATCTCTCGAG GGGCCTTATCTGGAGCTTTG-3' from mouse genomic DNA. The PCR product was purified and inserted into pGEM-T Easy vector (Promega, Madison, WI, USA). After confirmation of the sequences, the inserted product was cloned into the pGL4.70[hRlud (Promega, Madison, WI, USA) basic luciferase expression vector resulting in pGL4.70/FICT-promoter.

\section{Cell culture and Luciferase assay}

For the luciferase assay, we used four different cell lines including GH3 (mouse pituitary cell line), NIH 3T3 (mouse fibroblasts), PC12 (rat neuronal pheochromocytoma cells) and MCF7 (human breast cancer cell line). Cells were seeded into 24-well culture plates at $1 \times 10^{6}$ cells/well in DMEM supplemented with $10 \%$ fetal bovine serum. After $24 \mathrm{~h}$, cells were transfected with $1 \mu \mathrm{g}$ of pGL4.7/FICT-promoter or pGL4.70 empty vector (pGL4.7-Basic) by using lipofectamin2000 (Invitrogen, Carlsbad, CA, USA) according to the manufacturer's protocol. Luciferase activity was measured $48 \mathrm{~h}$ later with Renillaluciferase reporter system (Promega, Madison, WI, USA) according to the manufacturer's protocol. All experiments were performed in triplicate.

\section{Results and Discussion}

The present results suggest that there are negative regulatory elements located in the promoter region of FICT and miR-7b. We have confirmed expression of FICT and miR-7b in the hypothalamus, cortex, liver and testis by real-time PCR (Fig. 1). Expression of both genes in the hypothalamus and cortex appeared greatly co-elevated compared to other tissues, as expected. Analysis of the sequence revealed that

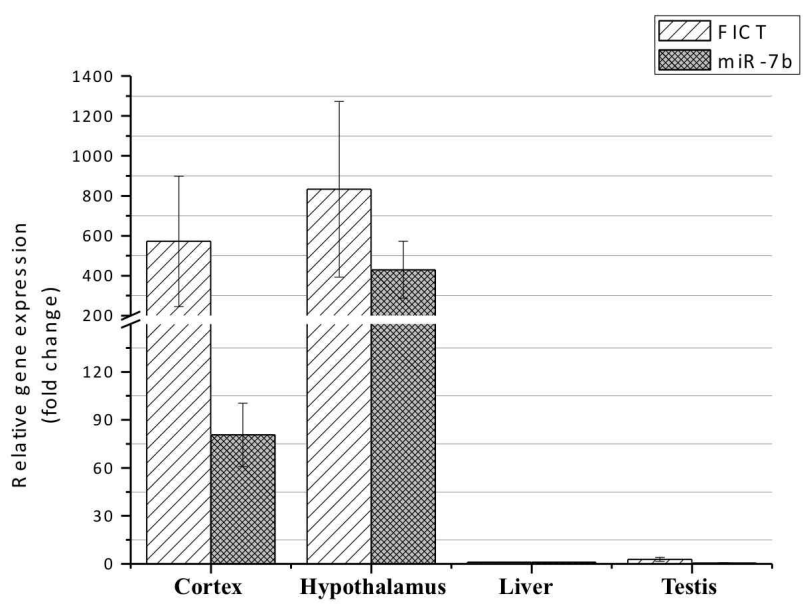

Fig. 1. The symmetry correlation between miR-7b and FICT gene expression in several tissues and high expression profiling of miR-7b and FICT in the brain. FICT mRNA expression levels were analyzed by real-time PCR and $\beta$-action was used for reference gene expression. Real-time PCR analysis of miR-7b in four tissues and U6 was used for reference control gene. FICT and miR-7b fold expression data were normalized to expression level of FICT and miR-7b in the liver, respectively. Data show the means from three independent experiments (error bars indicate standard deviations). 
$5^{\prime}$ upstream genomic DNA region of miR-7b and its host gene FICT have high homology with human miR-7-3 and its host gene PGSF1 (Figs. 2A and B). miR-7b, miR-7, FICT, and PGSF1 are brain specific genes, as shown by various analyses including microarray, in situ hybridization and northern blot [4-6,12]. Interestingly, although the host transcripts (both FICT and PGSF1) do not share homologous regions with each other, the pre-miRNAs sequences of human miR-7-3 and mouse miR-7b and their $5^{\prime}$ upstream regions are highly conserved (Fig. 2). This comparison led us to think that the $5^{\prime}$ conserved region might be the promoter for the miRNA and its host gene. In order to probe this idea, we cloned the $5^{\prime}$ upstream region of mouse FICT gene into a luciferase reporter vector. Then the construct was transfected into various cell lines. Surprisingly, relative luciferase activity (normalized to empty luciferase vector) was strongly decreased in GH3, PC12 and MCF7 cell lines but did not changed in NIH $3 \mathrm{~T} 3$ cells (Fig. 3). This finding suggests that the promoter region of miR-7b and FICT harbors tissue-specific negative cis elements. Several consensus sequences for cis elements are conserved between human and mouse (Fig. $2 B)$, suggesting they might have an important role in the regulation of gene expression. The putative promoter region of miR-7b and FICT does not alter promoter activity in fibroblasts (NIH 3T3), indicating the regulatory elements within this region are not involved in miR-7b and FICT gene expression in this cell line. Although we have not yet identified the transcription factors and their positive regulatory or tissue-specific elements that make the FICT and miR-7b expression specific in the brain, we have identified the region

A

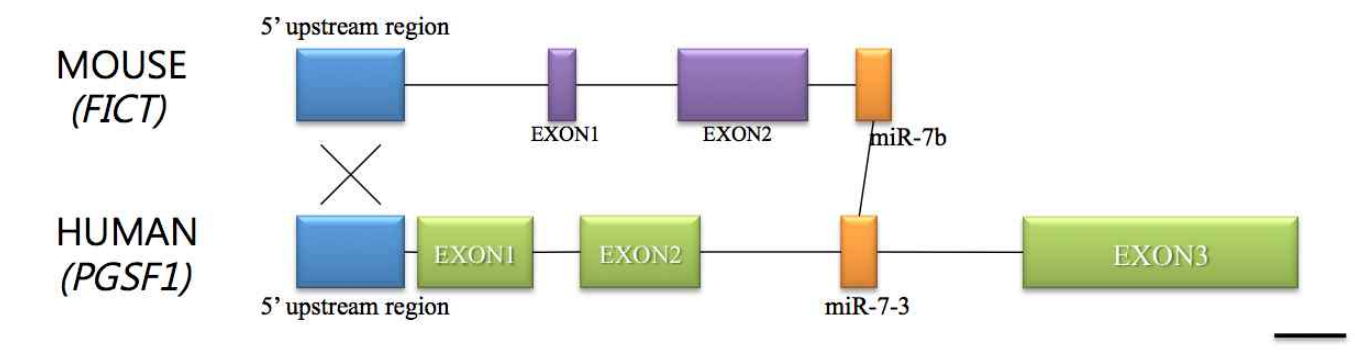

B

$500 \mathrm{bp}$
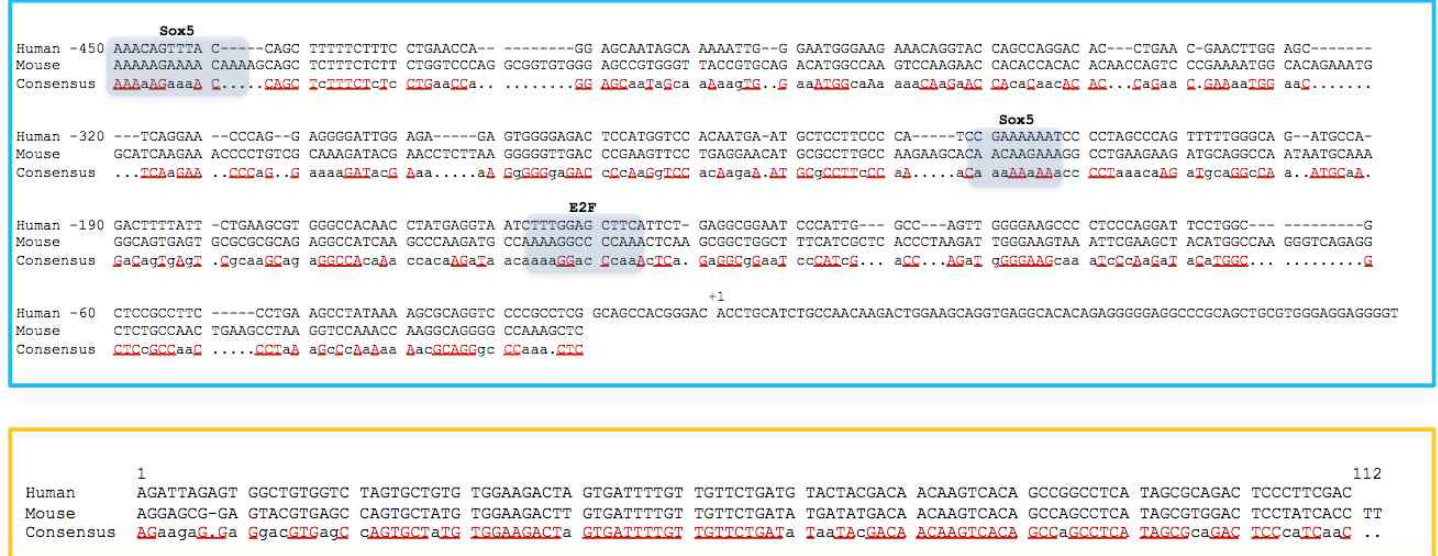

Fig. 2. Sequence comparison of the genomic DNA of mouse miR-7b, human miR-7-3 and their host genes. (A) Schematic representation of the genomic DNA of mouse miR-7b, human FICT genes. The size and relative positions of exons (purple boxes for FICT and green boxes for PGSF1) are shown. $5^{\prime}$ upstream homology region (blue boxes) and miRNA homology region (orange boxes) are also shown. (B) The 5' upstream regions of mouse miR-7b and human 7-3 were aligned in upper blue box. In the yellow box, precursor sequences of human miR-7-3 and mouse miR-7b were aligned. Nucleotides that are conserved are indicated by red and underlined letters at consensus sequences. The sequences are numbered relative to the position of the transcription start site, where negative numbers indicated sequences upstream of the start sites of human PGSF1 gene. The transcription start site of mouse FICT has not been exactly identified. Those sequences that may be conserved transcription factor binding sites are highlighted by gray shading. 


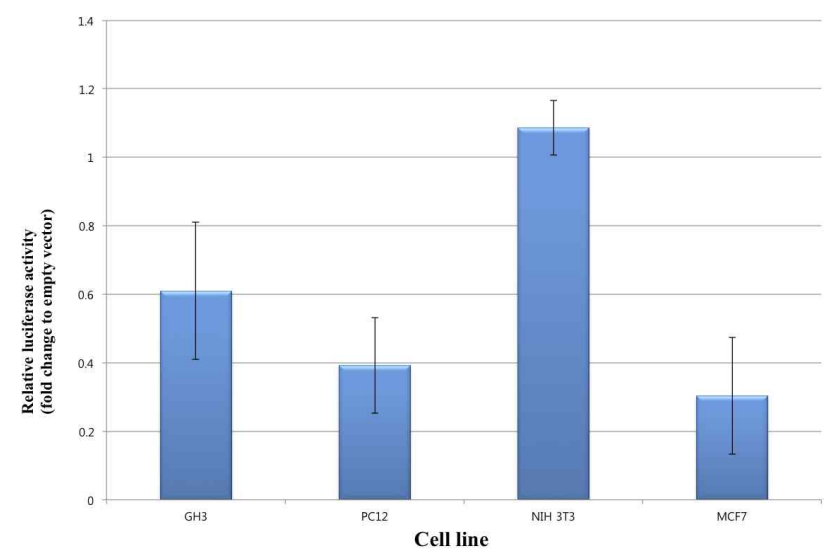

Fig. 3. Luciferase activity for the $5^{\prime}$ upstream conserved region of miR-7b. Luciferase activity was down-regulated in GH3, PC12 and MCF7 but not in NIH 3T3 cell lines by the putative promoter region of the FICT. Luciferase activity was normalized to empty luciferase vector activity. Thus, y-axis shows the change of fold activity that normalized to empty luciferase vector activity. Data show the means from three independent transfections (error bars indicate standard deviations).

that act as a negative regulatory region in certain cell types. One possibility is that tissue-specific miR-7b and FICT gene expression may result form the lack of specific activator as well as the presence of specific repressors in the cell lines we tested. Evolutionary well-conserved miRNA precursor sequences and their promoter regions confirm that the miRNA genes have crucial roles in regulating gene expression. Identification and analysis of miRNA gene promoters will open a new era of miRNA gene understanding.

\section{Acknowledgments}

The authors sincerely thank to Dr. W.S. Young III for critical reading of this manuscript. This research was supported by Kyungpook National University Research Fund 2010.

\section{References}

1. Bartel, D. P. 2004. MicroRNAs: genomics, biogenesis, mechanism, and function. Cell 116, 281-297.

2. Baskerville, S. and D. P. Bartel. 2005. Microarray profiling of microRNAs reveals frequent coexpression with neighboring miRNAs and host genes. Rna 11, 241-247.

3. Corpet, F. 1988. Multiple sequence alignment with hierarchical clustering. Nucleic Acids Res. 16, 10881-10890.

4. Farh, K. K., A. Grimson, C. Jan, B. P. Lewis, W. K. Johnston, L. P. Lim, C. B. Burge, and D. P. Bartel. 2005. The widespread impact of mammalian MicroRNAs on mRNA repression and evolution. Science 310, 1817-1821.

5. Junn, E., K.W. Lee, B.S. Jeong, T.W. Chan, J.Y. Im, and M.M. Mouradian. 2009. Repression of alpha-synuclein expression and toxicity by microRNA-7. Proc. Natl. Acad Sci. USA 106, 13052-13057.

6. Lee, H. J., M. Palkovits, and W. S. Young, $3^{\text {rd }}$. 2006. miR-7b, a microRNA up-regulated in the hypothalamus after chronic hyperosmolar stimulation, inhibits Fos translation. Proc. Natl. Acad. Sci. USA 103, 15669-15674.

7. Lee, J. E., S. M. Hollenberg, L. Snider, D. L. Turner, N. Lipnick, and H. Weintraub. 1995. Conversion of Xenopus ectoderm into neurons by NeuroD, a basic helix-loop-helix protein. Science 268, 836-844.

8. Lee, Y., M. Kim, J. Han, K. H. Yeom, S. Lee, S. H. Baek, and V. N. Kim. 2004. MicroRNA genes are transcribed by RNA polymerase II. EMBO J. 23, 4051-4060.

9. Mandel, G. and D. McKinnon. 1993. Molecular basis of neural-specific gene expression. Annu. Rev. Neurosci. 16, 323-345.

10. Nelson, P., M. Kiriakidou, A. Sharma, E. Maniataki, and Z. Mourelatos. 2003. The microRNA world: small is mighty. Trends Biochem Sci. 28, 534-540.

11. Quinn, J. P. 1996. Neuronal-specific gene expression--the interaction of both positive and negative transcriptional regulators. Prog. Neurobiol. 50, 363-379.

12. Tanaka, S., K. Tatsumi, K. Okubo, K. Itoh, S. Kawamoto, K. Matsubara, and N. Amino. 2002. Expression profile of active genes in the human pituitary gland. J. Molecular Endocrinol. 28, 33-44. 
초록 : 네거티브 유전자 조절인자를 포함하는 마이크로RNA, miR-7b의 프로모터

최지웅 ${ }^{1} \cdot$ 이헌진 ${ }^{1,2} \star$

( ${ }^{1}$ 경북대학교 치의학전문대학원 구강미생물학교실, ${ }^{2}$ 경북대학교 뇌과학연구소)

전형적인 마이크로 RNA는 주로 해당 마이크로RNA의 호스트 유전자와 동시에 발현하는 형상을 보인다. 마이 크로RNA miR-7b와 그 호스트 유전자인 FICT는 유전자 발현 조절부위인 프로모터를 함께 공유할 것으로 추정되 며, 이는 이 유전자들의 뇌 특이적인 발현 양상에 기여할 것으로 추정된다. 바이오인포메틱 방법을 이용하여 사람 과 마우스의 miR-7혹은 miR-7b의 프로모터 부위가 상호 유사성을 가짐을 확인하였고, 이 부위에 다양한 전자조 절 부위가 있는 것을 확인 하였다. 또한 이 가설을 증명하기 위하여 형광발현 리포터 유전자 시스템을 사용하여 형광발현 벡터에 마이크로 RNA miR-7b와 그 호스트 유전자인 FICT의 5' 전부위를 클로링하여 프로모터의 활성 정도를 다양한 세포주에서 확인하였다. 이 결과를 통하여 마이크로 RNA와 그 호스트 유전자인 FICT의 프로모터 에는 네거티브 유전자 조절인자를 포함하는 것을 확인 할 수 있었다. 